\title{
Potentiation of Neuronal NMDA Response Induced by Dehydroepiandrosterone and its Suppression by Progesterone: Effects Mediated via Sigma Receptors
}

\author{
Richard Bergeron, Claude de Montigny, and Guy Debonnel \\ Department of Psychiatry, Neurobiological Psychiatry Unit, MCGill University, Montreal, Quebec, Canada H3A $1 A 1$
}

We have shown previously that low doses of selective sigma $(\sigma)$-receptor ligands potentiate the excitatory response of pyramidal neurons to NMDA in the $\mathrm{CA}_{3}$ region of the dorsal hippocampus in the rat. Because progesterone competitively displaces the binding of the ligand $N-\left[{ }^{3} \mathrm{H}\right]$ allyl-normetazocine (SKF-10,047), the present studies were undertaken to determine in vivo the effect of neuroactive steroids on NMDAinduced excitation of rat $\mathrm{CA}_{3}$ pyramidal neurons. Low doses of dehydroepiandrosterone (DHEA) potentiated the NMDA response selectively and dose-dependently. The effect of DHEA was reversed by the selective $\sigma$ antagonist $N$-dipropyl-2-(4methoxy-3-(2-phenylethoxy)phenyl)-ethylamine monohydrochloride (NE-100) and by haloperidol, but not by spiperone. Progesterone had no effect by itself but reversed, at low doses, the potentiation of the NMDA response induced by DHEA as well as those induced by nonsteroidal $\sigma$ ligands. Neither pregnenolone nor pregnenolone sulfate had any effect on the NMDA response-nor did they antagonize the potentiation of the NMDA response induced by DHEA and by nonsteroidal $\sigma$ ligands. A pertussis toxin pretreatment, which inactivates $G_{1 / 0^{-}}$ proteins, abolished the potentiating effects of DHEA. Ovariectomy enhanced the potentiation of the NMDA response by the nonsteroidal $\sigma$ ligand di(2-tolyl)guanidine (DTG). There was a reciprocal occlusion of the effects of DHEA and DTG; DTG did not potentiate the NMDA response further after DHEA, and DHEA did not do so after DTG. These results suggest that some neuroactive steroids modulate the NMDA response via $\sigma$ receptors.

Key words: neurosteroids; hippocampus; electrophysiology; ovariectomy; haloperidol; DTG
Sigma $(\sigma)$ receptors are present in high density in the CNS (Walker et al., 1990) and in peripheral organs, with a particularly high density in the ovaries (Wolfe et al., 1989). Many psychotropic drugs such as antipsychotics and antidepressants have high affinity for $\sigma$ receptors (Su, 1982; Schmidt et al., 1989; Snyder and Largent, 1989; Itzhak and Kassim, 1990; Ferris et al., 1991). Several steroids, progesterone in particular, also bind with high affinity to $\sigma$ receptors (Su et al., 1988).

Previous studics have demonstratcd that low doses of selective $\sigma$ ligands, such as di(2-tolyl)guanidine (DTG) (Weber et al., 1986), 1-henzylspiro[1,2,3,4-tetrahydro-aphthalene-1,4-piperidine] (L-687,384) (Middlemiss et al., 1991; Barnes et al., 1992), (+)N-cyclopropylmethyl$\mathrm{N}$-methyl-1,4-diphenyl-1-ethyl-butyl-3- $\mathrm{N}$-1-ylamine hydrochloride (JO1784) (Roman et al., 1990), and (+)pentazocine (Steinfels et al., 1988) selectively potentiate the response of rat $\mathrm{CA}_{3}$ dorsal hippocampus pyramidal neurons to microiontophoretic applicalions of NMDA (Monnet et al., 1990, 1992; Martin et al., 1992; Walker and Hunter, 1994). This effect is reversed by other $\sigma$ ligands such as haloperidol, $(+) 3$ hydroxyphenyl- $N$-(1-propyl)piperidine [also known as (+)3-PPP], and $\alpha$-(4-fluorophenyl)-4-(5-fluoro-2-pyrimidinyl)-1-piperazine butanol (BMY-14802) (Largent et al., 1984; Tam and Cook, 1984; Taylor and

\footnotetext{
Received Aug. 8, 1995; revised Oct. 10, 1995; accepted Nov. 11, 1995.

This work was supported by the Medical Research Council of Canada, the Royal Victoria Hospital Research Institute, and the Fonds de la Recherche en Santé du Québec (FRSQ). G.D. received a scholarship from the FRSQ, and R.B. received a fellowship from the FRSO. We thank $T$. Vo for computer programming and statistical analyses, C. Bouchard for illustrations, and L. Martin for secretarial assistance.

Correspondence should be addressed to Richard Bergeron, Department of Psy chiatry. Neurohiological Psychiatry Init, McGill University, 1033 Pine Avenue West. Montreal, Quebec, Canada H3A IAl.

Copyright 1996 Society for Neuroscience $0270-6474 / 96 / 161193-10 \$ 05.00 / 0$
}

Dekleva, 1987), but not by spiperone, which has a binding profile similar to that of haloperidol except for its low affinity for $\sigma$ receptors (Monnet et al., 1990, 1992). We also have tested recently the novel and very selective $\sigma$ ligand $N$-dipropyl-2-(4-methoxy-3-(2-phenylethoxy)phenyl)ethylamine monohydrochloride (NE-100) (Okuyama et al., 1993). It proved extremely potent in blocking or reversing the potentiation of the NMDA response induced by $\sigma$ ligands such as DTG (Debonnel et al., 1995a). Therefore, $\sigma$ ligands acting like DTG have been denoted tentatively $\sigma$ "agonists," and $\sigma$ ligands acting like haloperidol have been denoted "antagonists" (Monnet et al., 1990). These data and several other reports from other laboratories using biochemical, neuroendocrinological, and behavioral models suggest the existence of a functional interaction between $\sigma$ and NMDA receptors, although the exact mechanism is not understood fully (for review, see Debonnel, 1993).

There are several types of $\sigma$ receptors; those classified as $\sigma_{1}$ and $\sigma_{2}$ have been characterized most extensively (Quirion et al., 1992). The most commonly used $\sigma$ ligands, including haloperidol and DTG, do not discriminate between $\sigma_{1}$ and $\sigma_{2}$ receptors (Quirion et al., 1992), whereas drugs such as (+)pentazocine, JO-1784, L-687,384, $N$-allyl-normetazocine [ + )SKF-10047], and NE-100 are selective for $\sigma_{1}$ receptors (Quirion et al., 1992; Chaki et al., 1994). However, recent data obtained in our laboratory have shown that pertussis toxin (PTX) pretreatment abolishes the potentiation induced by JO-1784, but not that induced by $(+)$ pentazocine (Monnet et al., 1994), which suggests that these two $\sigma$ ligands act on different $\sigma$-receptor subtypes. Moreover, the injection of colchicine in the dentate gyrus, which destroys the mossy fiber system (a major afference to $\mathrm{CA}_{3}$ pyramidal neurons), abolishes the potentiation of the NMDA response induced by DTG and JO-1784, but not that of (+)pentazocine, suggesting that the subtype of $\sigma$ receptors on which DTG and JO-1784 are acting is 
located presynaptically on the mossy-fiber terminal, whereas the subtype of $\sigma$ receptors on which $(+)$ pentazocine is acting is located postsynaptically (Debonnel et al., 1995b).

Several reports have shown that progesterone acts as a competitive inhibitor of $\left[{ }^{3} \mathrm{H}\right](+)$ SKF- 10047 or $\left[{ }^{3} \mathrm{H}\right]$ haloperidol (Su et al., 1988; McCann et al., 1994; Yamada et al., 1994; Ramamoorthy et al., 1995) at $\sigma$ receptors and have prompted us to assess the potential agonistic or antagonistic properties of progesterone, dehydroepiandrosterone (DHEA), and other neuroactive steroids (Paul and Purdy, 1992) in an in vivo electrophysiological paradigm.

\section{MATERIALS AND METHODS}

The experiments were carried out in vivo in the $\mathrm{CA}_{3}$ region of the rat dorsal hippocampus, in which the responsiveness of pyramidal neurons to microiontophoretic applications of NMDA, quisqualate (QUIS), and acetylcholine $(\mathrm{ACh})$ was assessed using extraccllular unitary recordings.

Preparation of animals. Male Sprague-Dawley rats weighing 200-250 gm were obtained from Charles River I aboratories (St. Constant, Quebec, Canada). Female rats of the same weight were obtained at day 1 or 3 of the menstrual cycle or 2 wceks after ovariectomy (OVX). Rats were housed three to four per cage with free access to food and water. They were maintained at constant temperature $\left(25^{\circ} \mathrm{C}\right)$ under a $12 \mathrm{hr} / 12 \mathrm{hr}$ light/dark cycle.

PTX pretreatment. The pretreatment with PTX ( $1 \mu \mathrm{g}$ in $2 \mu \mathrm{l}$ of physiological saline; Sigma, St. Louis, MO) consisted of lowering the tip of a $5 \mu \mathrm{l}$ Hamilton syringe unilaterally into the right dorsal hippocampus of chloral hydrate-anesthetized rats (anterior, $4.5 \mathrm{~mm}$; lateral, $4 \mathrm{~mm}$; and dorsal, $4 \mathrm{~mm}$ ) according to the atlas of Paxinos and Watson (1986). PTX was injected slowly over a period of $5 \mathrm{~min}$. Control rats were injected with an equal volume of physiological saline under the same conditions. In vivo electrophysiological experiments were carried out 5-7 d later.

Drugs. The following substances were used: DTG (Aldrich, Milwatukee, WI); JO-1784, a gift from J. Junien (Institut de Recherche Jouveinal, Fresnes, France); L-687,384, a gift from L. Iversen (Merck-Sharp and Dohmc, Tyler Park, UK); NMDA and ACh (Sigma); QUIS (Tocris Neuramin, Buckburst Hill, Essex, UK); haloperidol (McNeil Laboratories, Stouffville, Ontario, Canada); spiperone, (+)pentazocine, progesterone, pregnenolone, pregnenolone-sulfate, and DHEA (Research Biochemicals, Natick, MA); NE-100, a gift from S. Okuyama (Taisho Pharmaceutical, Ohmiya, Japan).

Preparation of micropipettes. Microiontophoretic applications and extracellular unitary recordings were performed with 5-barrel glass micropipettes prepared in a conventional manner (Haigler and Aghajanian, 1974). Three of the side barrels used for microiontophoresis contained (in mM): NMDA 10 (in NaCl 200), $\mathrm{pH}$ 8, QUIS 1.5 (in $\mathrm{NaCl} 400$ ), $\mathrm{pH} 8$, and $\mathrm{ACh} 20$ (in $\mathrm{NaCl} 200$ ), $\mathrm{pH}$ 4. The remaining side harrel, usect for automatic current balancing, and the central barrel, used for extracellular unitary recording, were filled with $2 \mathrm{M} \mathrm{NaCl}$ saturated with Fast Green (FCF; Aldrich).

Recordings from $\mathrm{CA}_{3}$ dorsal hippocampus pyramidal neurons. For the electrophysiological experiments, rats were anesthetized with urethane (1.25 $\mathrm{g} / \mathrm{kg}$, i.p.) and mounted in a stereotaxic apparatus. Body temperature was maintained at $37^{\circ} \mathrm{C}$ throughout the experiment. After removal of the dura mater, the micropipette was lowered into the $\mathrm{CA}_{3}$ region of the dorsal hippocampus (lateral, $+4.2 \mathrm{~mm}$; anterior, $+4.2 \mathrm{~mm}$ from lambda: dorsal. -3.5 to $-4.5 \mathrm{~mm}$ from the cortical surface). Pyramidal ncurons were identified by their long-duration $(0.8-1.5 \mathrm{msec})$ and large-amplitude (0.5-2 $\mathrm{mV}$ ) action potentials and by the presence of characteristic complex spike discharges alternating with simple spike activity (Kandel and Spencer. 1961).

Neuronal firing activity was monitored via an oscilloscope after signal magnification by a high-input impedance amplifier. Action potentials were detected by a differential amplitude discriminator generating square pulses, which were stored on-line and forwarded to a paper chart recorder generating integrated firing-rate histograms. Alternate microiontophoretic applications of $50 \mathrm{sec}$ of each excitatory substance (NMDA, QUIS, and ACh) separated by $50 \mathrm{sec}$ retention periods were carried out continuously during the duration of the recording. The duration of the microiontophoretic applications and the intensity of the currents used also were stored on-line. The effects of their applications on pyramidal neuron firing activity were expressed as the number of spikes generated per nanocoulomb (nC; $1 \mathrm{nC}$ is the charge generated by $1 \mathrm{nA}$ applied for $1 \mathrm{sec}$ ).

After a neuron was isolated, it was recorded for a period of at least 20 min before any drug was injected. The recording was stored on-line without interruption for the duration of the experiment. Five to six applications of each excitatory substance (NMDA. QUIS, and ACh) were carried out before the drugs studied were injected or applied microiontophoretically. The effects of drugs studied appeared within a period of 10 min after their intravenous injection. The calculations were carried out when the maximal effect of the drug was achieved (within the first 20 min). At the end of the experiment, a $-27 \mu \mathrm{A}$ current was passed through the central barrel for 20 min to deposit Fast Green FCF for subsequent histological verification of recording sites.

Experimental series. Neuroactive steroids were prepared in a solution of $40 \%$ polyethylene glycol. The $\sigma$ ligands were prepared in physiological saline, and they were administered via a lateral tail vein. In all experimental series, only one dose of each drug was administered to one rat while rccording from one neuron.

In the first series of experiments, several doses of each drug were tested to generate dose-response curves. Progesterone, DHEA, pregnenolone, and pregnenolone sulfate were tested at doses ranging from $1 \mu \mathrm{g} \mathrm{to} 2 \mathrm{mg} / \mathrm{kg}$. In the second series, progesterone $(20 \mu \mathrm{g} / \mathrm{kg}$, i.v.) was tested as an antagonist of the potentiation of the NMDA response induced by the previous administration of a low dose of DHEA or of the following nonsteroid a ligands: DTG $1 \mu \mathrm{g} / \mathrm{kg}$, i.v.; L-687,384 $1 \mu \mathrm{g} / \mathrm{kg}$, i.v.; JO- $17845 \mu \mathrm{g} / \mathrm{kg}$, i.v.; (+)pentazocine $10 \mu \mathrm{g} / \mathrm{kg}$, i.v. In the third series, rats were pretreated with a local injection of PTX to assess the possible involvement of $\sigma$ receptors coupled with $G_{i, s}$-proteins in the potentiation of the neuronal response to NMDA by neuroactive steroids. In the fourth series, we have examined the possibility of a reciprocal occlusion of the effects of DTG and DHEA. In the final series, the degree of the potentiation of the NMDA response induced by DTG (1 $\mu \mathrm{g} / \mathrm{kg}$, i.v.) was measured in male rats, in female rats at days 1 and 3 of the menstrual cycle, and in OVX rats 14 d after the surgery.

Calculations. The computer calculated the effect of each $50 \mathrm{sec}$ microiontophoretic application of an excitatory substance as the total number of spikes generated $/ \mathrm{nC}$. Each value was calculated by the computer as the mean of the effect of three consecutive applications of the same excitatury

Figure 1. A. Integrated firing-rate histogram of a $\mathrm{CA}_{3}$ dorsal hippocampus pyramidal neuron illustrating the effects of microiontophoretic applications of NMDA and QUIS before and after the injection of DHEA (arrow at left) and after the subsequent administration of haloperidol (arm at right). In this and the subsequent integrated firing-rate histograms, bars indicate the duration of applications for which currents are given (in $\mathrm{nA}$ ), and open circles represent an interruption of the illustration of the continuous recording. $B$, Dose-response curve of the effect of the intravenous administration of DHEA on the neuronal activation of $\mathrm{CA}_{3}$ dorsal hippocampus pyramidal neurons induced by microiontophoretic applications of NMDA. Each dof represents the effect of one dose of the drug administered to one rat while recording from one neuron in this and subsequent dose-response curves. The effect was assessed by determining the ratio $\left(N_{2}: N_{1}\right)$ of the number of spikes generated per nC of NMDA before $\left(N_{l}\right)$ and after $\left(N_{2}\right)$ the injection of the drug. $C$, Responsiveness. expressed as the number of spikes generated per $\mathrm{nC}$ (mean $\pm \mathrm{SEM}$ ), of $\mathrm{CA}_{3}$ dorsal hippocampus neurons to microiontophoretic applications of NMDA before (open columins) and after (gray columns) the administration of DHEA and after the subsequent aldministration of haloperidol (dark columns). The number within the open columns indicates the number of neurons tested ( 1 neuron/rat in this and subsequent bar chart histograms). $D$. Responsiveness, expressed as the number of spikes generated per $\mathrm{nC}$ (mean $\pm \mathrm{SEM}$ ), of $\mathrm{CA}_{3}$ dorsal hippocampus neurons to microiontophoretic applications of NMDA before (open columns) and after (gray columns) the administration of DHEA and after the subsequent administration of spiperone (dark columns). The number within the open column indicates the number of neurons tested ( 1 neuron/rat in this and subsequent bar chart histograms). E, Responsiveness, expressed as the number of spikes generated per nC (mean \pm SEM), of CA dorsal hippocampus neurons to microiontophoretic applications of NMDA before (open columns) and after (gray columns) the administration of DHEA and after the subsequent administration of saline (dark columns). $F$, Responsiveness, expressed as the number of spikes generated per $n C$ (mean $+S F M$ ), of $C A_{3}$ dorsal hippocampus neurons to microiontophoretic applications of NMDA before (open columns) and after (gray columns) the administration of DHEA and after the subsequent administration of the selective $\sigma$ antagonist NE-100 (dark collumns). Asterisks in $C-F$ indicate $p<0.05$ using paired Students $t$ test. 
A

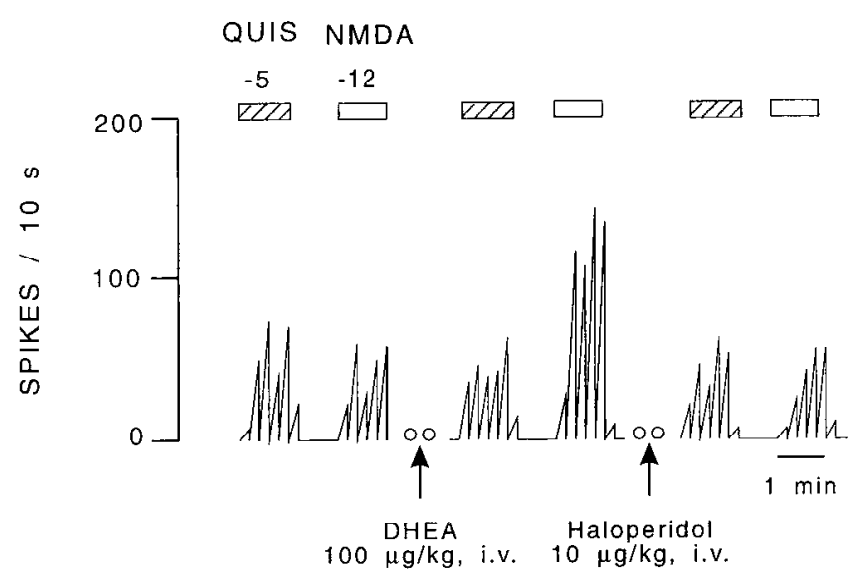

C

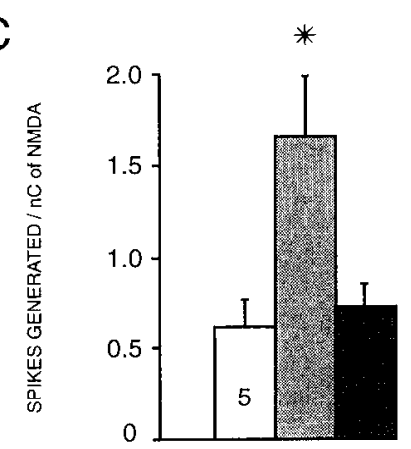

$\square$ Control
DHEA $(250 \mu \mathrm{g} / \mathrm{kg}$, i.v. $)$

Haloperidol $(20 \mu \mathrm{g} / \mathrm{kg}$, i.v.

E

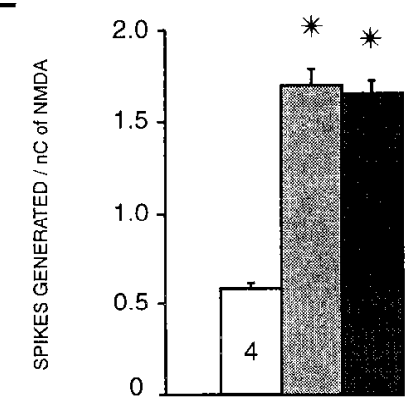

$\square$ Control

DHEA (250 $\mu \mathrm{g} / \mathrm{kg}$, i.v.)

- Salin
B

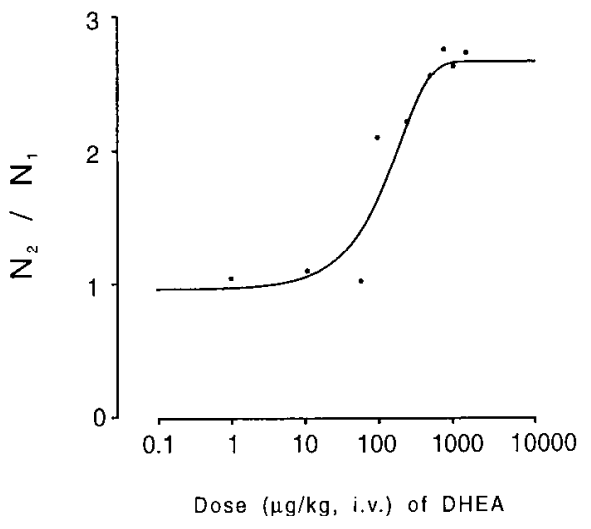

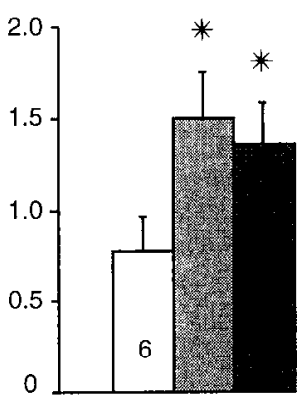

$\square$ Control

DHEA $(250 \mu \mathrm{g} / \mathrm{kg}$, i.v.)

1 Spiperone $(20 \mu \mathrm{g} / \mathrm{kg}$, i.v. $)$

F

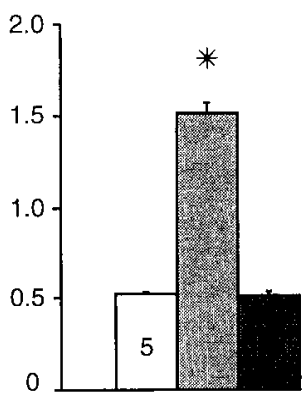

Control

DHEA $(250 \mu \mathrm{g} / \mathrm{kg}$, i.v. $)$

DE-100 $(25 \mu \mathrm{g} / \mathrm{kg}$, i.v. $)$ 

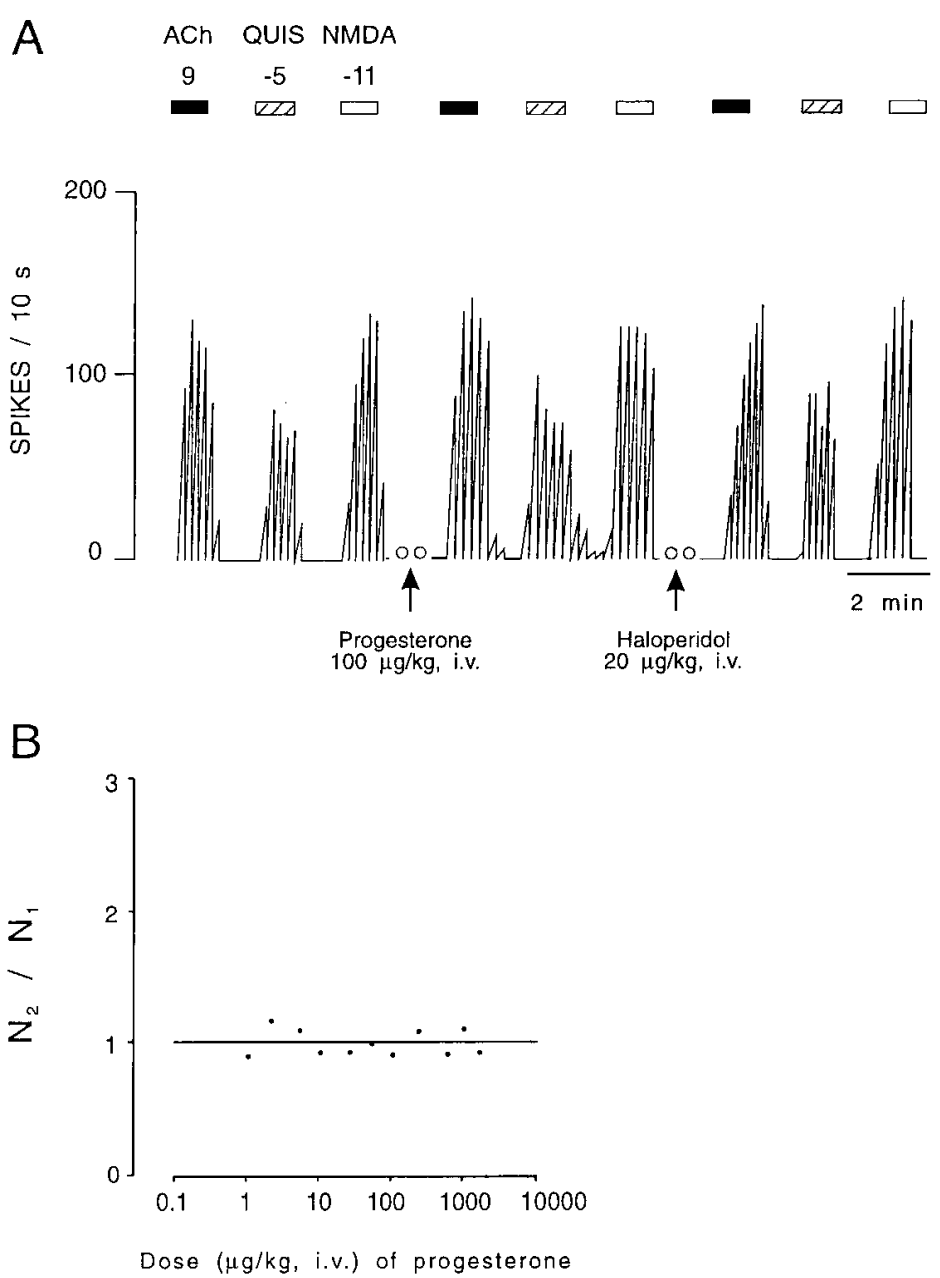

Figure 2. $A$, Integrated firing-rate histogram of a $\mathrm{CA}_{3}$ dorsal hippocampus pyramidal neuron illustrating the effect of microiontophoretic applications of NMDA, QUIS, and $A C h$ before and after the injection of progesterone (arrow at left) and after the subsequent injection of haloperidol (arrow at right; see legend to Fig. 1). B, Doseresponse curve of the effect of the injection of progesterone on the neuronal activation of $\mathrm{CA}_{3}$ dorsal hippocampus pyramidal neurons induced by microiontophoretic applications of NMDA. $C$, Responsiveness, expressed as the number of spikes generated per $\mathrm{nC}$ (mean $\pm \mathrm{SEM}$ ), of $\mathrm{CA}_{3}$ dorsal hippocampus pyramidal neurons to microiontophoretic applications of NMDA before (open columns) and after (gray columns) the administration of DHEA or progesterone and after the subsequent adininistration of either steroid (dark columns). Asterisk indicates $p<0.05$ using paired Student's $t$ test.
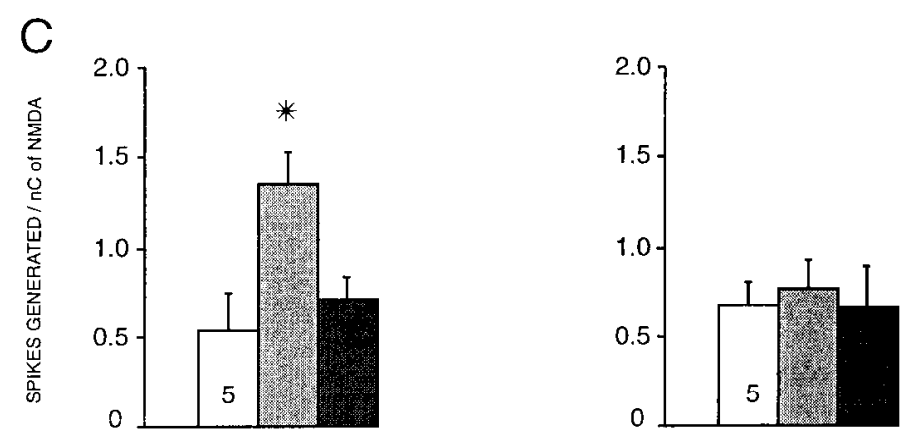

substances. The effects of the intravenous administration of the drugs studied were assessed when the maximal effect was achieved, by determining the ratio $\left(N_{2}: N_{1}\right)$ of the number of spikes generated/nC of each of the three excitatory substances ACh, QUIS, and NMDA before $\left(N_{1}\right)$ and after $\left(N_{2}\right)$ the injection of the drug. The dose-response curves of the effects of intravenous administration of $\sigma$ ligands were obtained by fitting experimental data to general logistic equations obtained with the software Tablccurve (version 3.0, Jandel Scientific, San Rafael, CA).

Statistical analyses. All results are expressed as mean \pm SEM of the number of spikes generated/nC of NMDA, QUIS, or ACh. Statistical significance was assessed using Student's $t$ test with Dunnett's correction for multiple comparisons. Covariance analysis was used to compare the degree of the potentiation of the NMDA response induced by DTG ( 1 $\mu \mathrm{g} / \mathrm{kg}$, i.v.) in male and in non-OVX and OVX female rats; $p \leq 0.05$ was considered significant.

\section{RESULTS}

All recordings were obtained from the stratum pyramidale of the dorsal hippocampal $\mathrm{CA}_{3}$ region, as confirmed by histological 

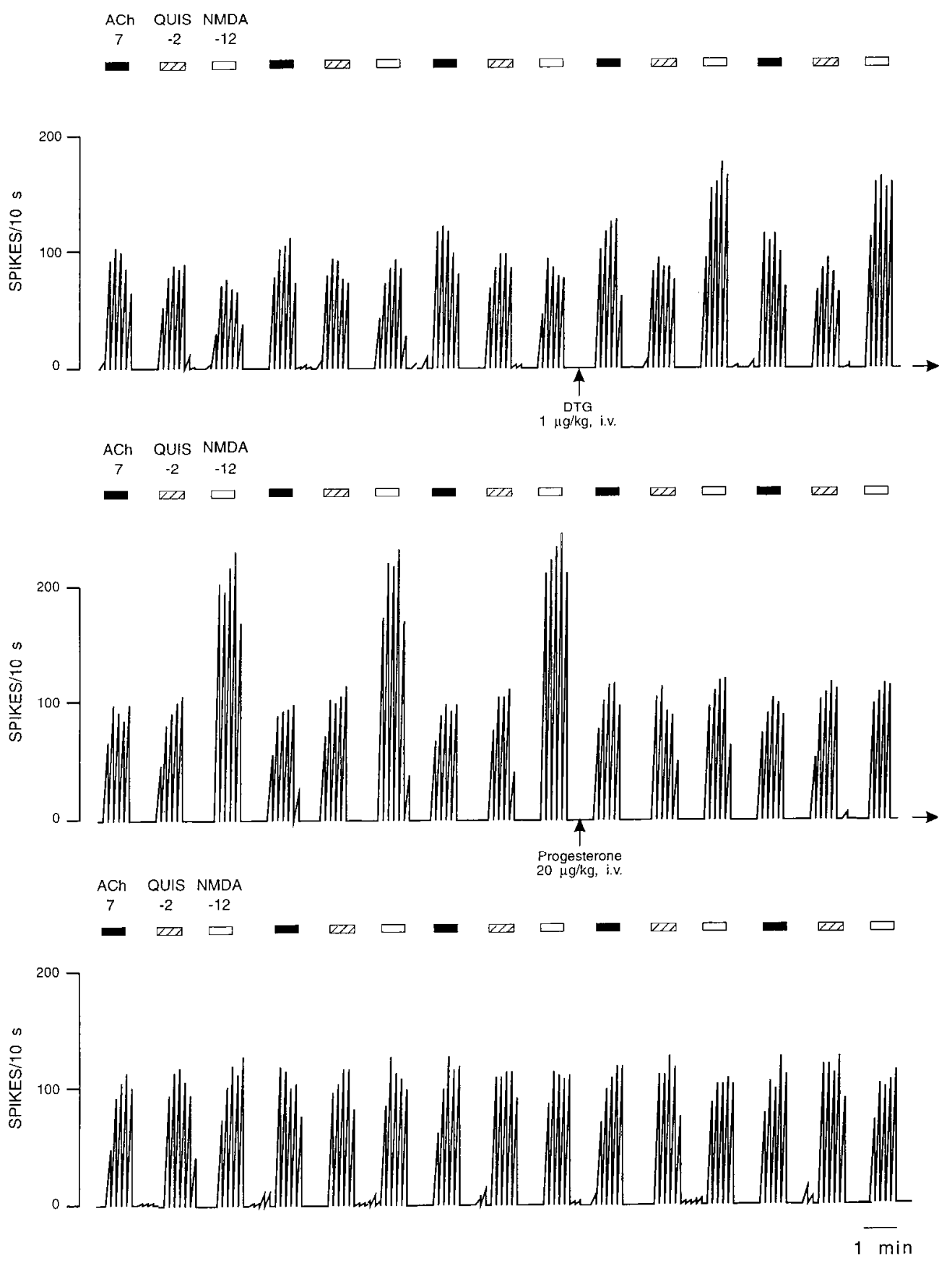

Figure 3. Continuous integrated firingrate histogram of a $\mathrm{CA}_{3}$ dorsal hippocampus pyramidal neuron illustrating the effect of microiontophoretic applications of NMDA, QUIS, and $A C h$ before and after the administration of DTG (arrows) and after the administration of progesterone. Time scale applies to the three traces.

verification of the Fast Green FCF deposit left at the end of each experiment.

The intravenous injection of the vehicle $(40 \%$ polyethylene glycol), used for preparing the solutions of neuroactive steroids, affected neither the spontaneous firing activity of dorsal hippocampus $\mathrm{CA}_{3}$ pyramidal neurons nor their response to NMDA, QUIS, and ACh.

\section{Effects of DHEA}

The intravenous administration of $100 \mu \mathrm{g} / \mathrm{kg}$ DHEA induced a twofold increase of the response of dorsal hippocampal CA3 pyramidal neurons to microiontophoretic applications of NMDA without affecting their response to QUIS (Fig. 1 $A$ ). The effect of DHEA was dose-dependent, and a maximal potentiation was obtained at a dose of $500 \mu \mathrm{g} / \mathrm{kg}$, i.v. (Fig. $1 B$ ). No additional potentiation was obtained by increasing the dose of DHEA up to $2 \mathrm{mg} / \mathrm{kg}$, i.v. (Fig. 1). This enhancing effect of DHEA lasted for at least $40 \mathrm{~min}$. The potentiation of the NMDA response by DHEA was reversed by haloperidol $(20 \mu \mathrm{g} / \mathrm{kg}$, i.v.; Fig. $1 C)$, but not by spiperone $(20 \mu \mathrm{g} / \mathrm{kg}$, i.v.; Fig. $1 D)$ and not by the intravenous administration of saline (Fig. $1 E$ ). Moreover, NE-100, a novel selective $\sigma$ antagonist (Okuyama et al., 1993), at a dose of 25 $\mu \mathrm{g} / \mathrm{kg}$, i.v., also suppressed the potentiation of the NMDA response induced by DHEA (Fig. $1 F$ ).

\section{Effects of progesterone}

At doses ranging from 1 to $2000 \mu \mathrm{g} / \mathrm{kg}$, i.v., progesterone did not affect the neuronal response induced by microiontophoretic applications of NMDA (Fig. $2 A, B$ ), QUIS, or ACh. However, progesterone, at a dose of $20 \mu \mathrm{g} / \mathrm{kg}$, i.v., prevented and reversed the 


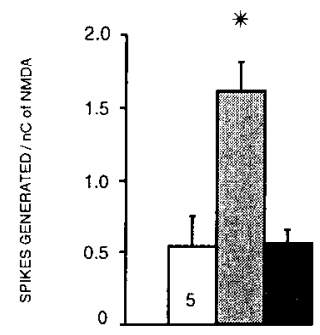

Control

DTG $(1 \mu \mathrm{g} / \mathrm{kg}, \mathrm{i} . v$. $)$

Progesterone $(20 \mu \mathrm{g} / \mathrm{kg}$, i.v. $)$
B

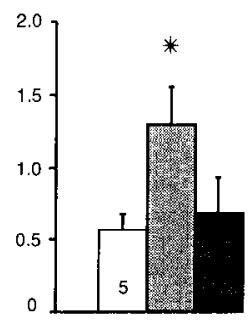

Control

JO-1784 (5 $\mu \mathrm{g} / \mathrm{kg}$, i.v. $)$

Progesterone $(20 \mu \mathrm{g} / \mathrm{kg}$, i.v.)

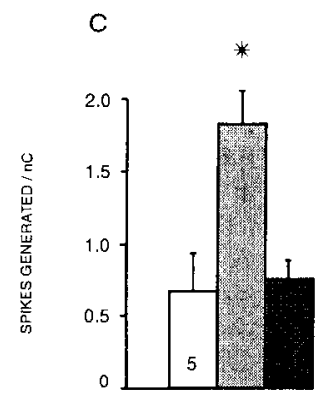

D
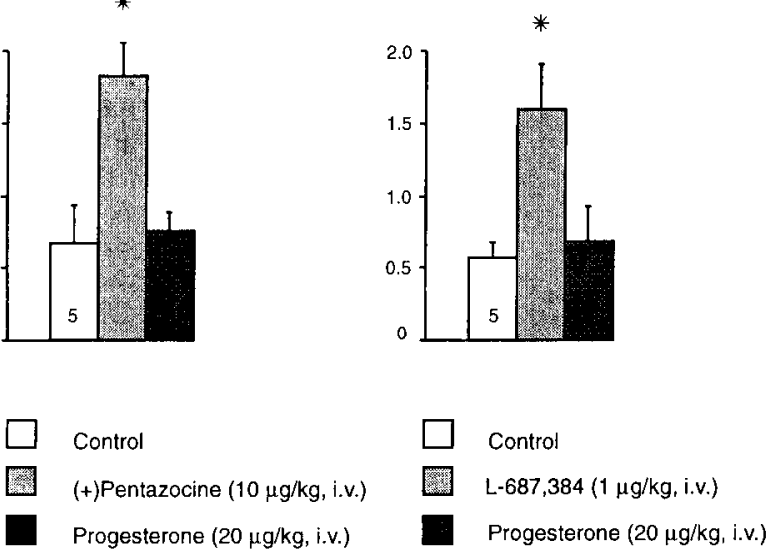

$E$

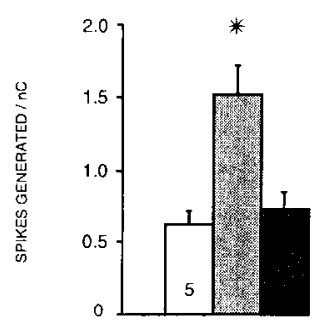

$\mathrm{F}$
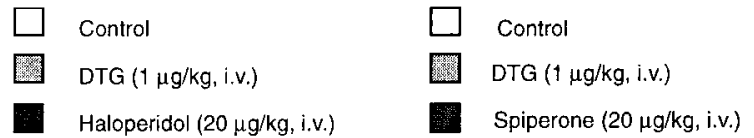

Figure 4. Responsiveness, expressed as the number of spikes generated per $\mathrm{nC}$ (mean $\pm \mathrm{SEM}$ ), of $\mathrm{CA}_{3}$ dorsal hippocampus pyramidal neurons to microiontophoretic applications of NMDA before (open columns) and after (gray columns) the intravenous administration of DTG $(A)$, JO-1784 $(B),(+)$ pentazocine $(C)$, and L-687384 $(D)$, and after the subsequent intravenous administration of progesterone $(A-D)$, haloperidol $(E)$, or spiperone $(F)$ (dark columns). Asterisks indicate $p<0.05$ using paired Student's $t$ test. potentiation of the NMDA response by DHEA $(250 \mu \mathrm{g} / \mathrm{kg}$, i.v.; Fig. $2 C$ ). To investigate the possibility that this effect of progesterone could be mediated via $\sigma$ receptors, low doses of the selective $\sigma$ ligands DTG (1 $\mu \mathrm{g} / \mathrm{kg}$, i.v.; Fig. 3), L-687,384 (1 $\mu \mathrm{g} / \mathrm{kg}$, i.v.), JO-1784 (5 $\mu \mathrm{g} / \mathrm{kg}$, i.v.), and (+)pentazocine $(10 \mu \mathrm{g} / \mathrm{kg}$, i.v. $)$ were administered to naive rats as illustrated for DTG in Figure 3. Progesterone $(20 \mu \mathrm{g} / \mathrm{kg}$, i.v.; Fig. $4 A-D)$ reversed the potentiation induced by the nonsteroidal $\sigma$ ligands. Haloperidol (2n) $\mu \mathrm{g} / \mathrm{kg}$, i.v.; Fig. $4 E)$, but not spiperone $(20 \mu \mathrm{g} / \mathrm{kg}$, i.v.; Fig. $4 F)$, also reversed the effect of DTG as reported previously (Monnet et al., 1990; Bergeron et al., 1993).

\section{Effects of pregnenolone and pregnenolone sulfate}

The effects of pregnenolone and pregnenolone sulfate were assessed in the same paradigm. At doses ranging from 1 to 2000 $\mu \mathrm{g} / \mathrm{kg}$, i.v., these two neuroactive steroids did not modify NMDA-, QUIS-, or ACh-induced neuronal responses. The efficacy of these two neuroactive steroids in reversing the potentiation of the NMDA response induced by a previous administration of DHEA $(100 \mu \mathrm{g} / \mathrm{kg}$, i.v.), as wcll as by other nonstcroidal $\sigma$ agonists, also was tested. Pregnenolone and pregnenolone sulfate neither reversed nor prevented the potentiation of the NMDA response induced by DHEA (Fig. $5 A, B$ ). Similarly, neither pregnenolone nor pregnenolone sulfate suppressed the potentiation of the NMDA response induced by the nonsteroidal $\sigma$ agonists DTG (1 $\mu \mathrm{g} / \mathrm{kg}$, i.v.; Fig. 5C,D), L-687,384 (1 $\mu \mathrm{g} / \mathrm{kg}$, i.v. ), JO-1784 (5 $\mu \mathrm{g} / \mathrm{kg}$, i.v.), or (+)pentazocine $(10 \mu \mathrm{g} / \mathrm{kg}$, i.v.) (data not shown for the latter three compounds).

\section{Effect of coadministration of DHEA and DTG}

To test the possibility that DHEA and nonsteroidal $\sigma$ ligands both activate $\sigma$ receptors, we have examined the possibility of a reciprocal occlusion of the effects of DHEA and DTG. The microiontophoretic applications of DTG $(20 \mathrm{nA})$ produced, as observed previously (Monnet et al., 1990; Bergeron et al., 1995a), a twofold increase in the neuronal response to NMDA. The injection of DHEA at $200 \mu \mathrm{g} / \mathrm{kg}$, i.v., failed to elicit an increase in NMDA response. Conversely, the intravenous administration of DHEA at $200 \mu \mathrm{g} / \mathrm{kg}$ also induced a threefold increase in the neuronal response to NMDA, and the subsequent microiontophoretic applications of DTG (20 $\mathrm{nA})$ failed to elicit an increase in NMDA response (Fig. 6).

\section{Effect of PTX pretreatment on the potentiation induced by DHEA}

PTX, which inactivates $G_{i / o}$-proteins via ADP ribosylation, was used to assess the possible involvement of these proteins in the modulation of NMDA-induced neuronal activation in the $\mathrm{CA}_{3}$ region of the rat dorsal hippocampus by DHEA. The in vivo PTX pretreatment affected neither the spontaneous firing activity of $\mathrm{CA}_{3}$ pyramidal neurons nor their responsiveness to NMDA, QUIS, or ACh, which is in agreement with previous data (Monnet et al., 1994). DHEA, at a dose of $250 \mu \mathrm{g} / \mathrm{kg}$, i.v. (a dose producing a more than twofold increase of the NMDA response in control rats), failed to produce any potentiation of the NMDA response in PTX-pretreated rats (Fig. $7 A, B$ ). We have reported previously that PTX pretreatment abolishes the potentiation of the NMDA response by $\mathrm{JO}-1784$, but not that induced by $(+)$ pentazocine, and this effect of $(+)$ pentazocine was still reversed by a low dose of haloperidol (Monnet et al., 1994). In the present series, the potentiating effect of $(+)$ pentazocine $(10 \mu \mathrm{g} / \mathrm{kg}$, i.v.) was still present in PTX-treated rats; this effect of $(+)$ pentazocine was reversed readily by progesterone $(20 \mu \mathrm{g} / \mathrm{kg}$, i.v.; Fig. $7 C, D)$. 


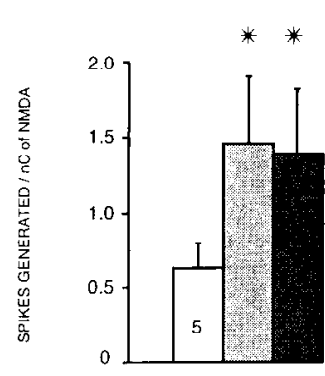

DHEA $(250 \mu \mathrm{g} / \mathrm{kg}, \mathrm{i} . v$.

Pregnenolone sulfate $\left(250 \mu \mathrm{g} / \mathrm{kg}, \mathrm{i} . \mathrm{v}_{1}\right)$

B

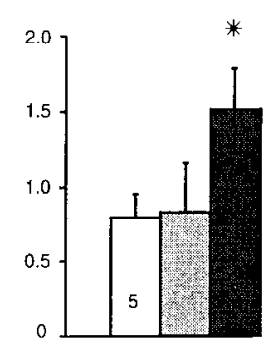

$\square$ Control

Pregnenolone $(2 b 0 \mu \mathrm{g} / \mathrm{kg}$, i.v. $)$
DHEA $(250 \mu \mathrm{g} / \mathrm{kg}$, i.v. $)$

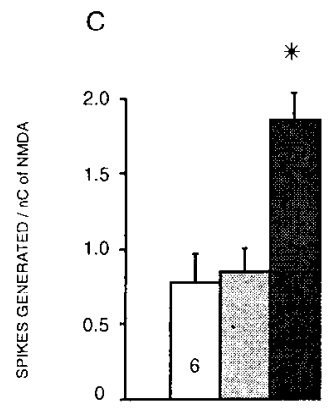

Control

Pregnenolone $(250 \mu \mathrm{g} / \mathrm{kg}$, i.v. $)$

DTG $(1 \mu \mathrm{g} / \mathrm{kg}$, i.v. $)$
D

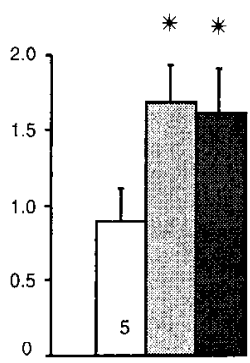

Figure 5. Responsiveness, expressed as the number of spikes generated per $\mathrm{nC}$ (mean $\pm \mathrm{SEM})$, of $\mathrm{CA}_{3}$ dorsal hippocampus pyramidal neurons to microiontophoretic applications of NMDA before (open columns) and after (gray columns) the administration of DHEA $(A)$, pregnenolone $(B, C)$, or DTG $(D)$, and after the subsequent administration of pregnenolone sulfate $(A, D)$, DHEA $(B)$, or DTG $(C)$ (dark columns). Asterisks indicate $p<0.05$ using paired Student's $t$ test.

\section{Effect of OVX on the potentiation induced by DTG}

In the final series of experiments, we measured the magnitude of the potentiation induced by DTG ( $1 \mu \mathrm{g} / \mathrm{kg}$, i.v.) in male rats and in female rats at days 1 and 3 of the menstrual cycle, as well as 2 weeks after OVX. As shown in Figure 8, no significant difference was found between the degrees of potentiation induced by DTG in male rats and non-OVX female rats at either day 1 or day 3 of the menstrual cycle. In these three groups, the potentiation of the NMDA response induced by DTG was suppressed completely by progesterone $(20 \mu \mathrm{g} / \mathrm{kg}, \mathrm{i.v}$.) and by haloperidol (20 $\mu \mathrm{g} / \mathrm{kg}$, i.v.; Fig. 8 ). However, the degree of the potentiation produced by DTG in OVX rats was significantly greater than that observed in the three other groups (Fig. 8). Moreover, in OVX rats, one dose of $20 \mu \mathrm{g} / \mathrm{kg}$, i.v., progesterone reversed DTG-induced potentiation only partially. Such a dose of progesterone completely reversed the effect of DTG in male and non-OVX female rats (Fig. 8). In OVX rats, a second dose of $20 \mu \mathrm{g} / \mathrm{kg}$, i.v., progesterone or a subsequent injection of $20 \mu \mathrm{g} / \mathrm{kg}$, i.v., haloperidol was required to obtain a complete suppression of the potentiation of the NMDA response induced by DTG (Fig. $8 D$ ).

\section{DISCUSSION}

The present results indicate that DHEA at very low doses selectively potentiates, in a dose-dependent manner, the neuronal response to microiontophoretic applications of NMDA onto pyramidal neurons in the $\mathrm{CA}_{3}$ region of the rat dorsal hippocampus (Fig. 1). This potentiation is reversed by NE-100 and haloperidol, but not by spiperone or saline (Fig. 1). Progesterone, at doses ranging from $1 \mu \mathrm{g} / \mathrm{kg}$ to $2 \mathrm{mg} / \mathrm{kg}$, i.v., does not modify the NMDA response by itself, but suppresses at the very low dose of $20 \mu \mathrm{g} / \mathrm{kg}$, i.v., potentiation of the neuronal response to NMDA induced by DHEA as well as by several nonsteroidal $\sigma$ ligands (Figs. 2-4). Pregnenolone and pregnenolone sulfate neither modify the NMDA response nor prevent or suppress the potentiation of the NMDA response induced by DHEA and by nonsteroidal $\sigma$ agonists (Fig. 5).

Several interactions between the NMDA-receptor complex and some neuroactive steroids have been documented (Wu et al., 1991; Irwin et al., 1992; Maione et al., 1992; Bowlby, 1993). In particular, pregnenolone sulfate augments NMDA receptormediated elevations in intracellular $\mathrm{Ca}^{2+}$ in cultured rat hippocampal neurons, presumably via a potentiation of the glutama- 

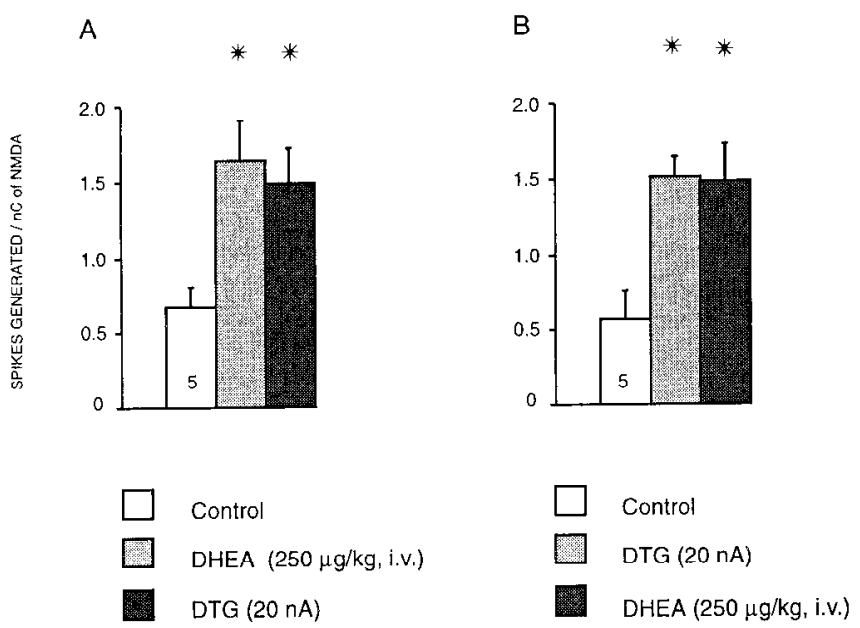

Figure 6. Responsiveness, expressed as the number of spikes generated per $\mathrm{nC}$ (mean $\pm \mathrm{SEM}$ ), of $\mathrm{CA}_{3}$ dorsal hippocampus pyramidal neurons to microiontophoretic applications of NMDA in control rats before (open columns) and after (gray columns) the administration of DHEA $(A)$ or DTG $(B)$, and after the subsequent administration of DTG $(A)$ or DHEA (B) (dark columns). Asterisks indicate $p<0.05$ using paired Student's $t$ test.

tergic activation of the NMDA receptor (Irwin et al., 1992). In this preparation, NMDA-receptor activation produces a greater inward current of $\mathrm{Ca}^{2+}$ in the presence of pregnenolone sulfate; this effect has been attributed to a direct action of the steroid on the NMDA-receptor complex (Bowlby, 1993). Pregnenolone sulfate also enhances NMDA-gated currents in spinal cord neurons and increases significantly the proconvulsant activity of NMDA (Maione et al., 1992). The mechanisms whereby neurosteroids affect glutamatergic transmission are not elucidated completely. A growing body of evidence suggests that many neuroactive steroids can rapidly alter the excitability of neurons via a modulation of $\mathrm{GABA}_{\mathrm{A}}$ receptors acting as agonists (e.g., pregnenolone sulfate and estrogen) or as antagonists (e.g., progesterone) (Majewska et al., 1986, 1990; Lambert et al., 1987; Majewska and Schwartz, 1987; Mienville and Vicini, 1989; Morrow et al., 1990; Wu et al., 1990; Purdy ct al., 1991). The interactions observed in the present study are unlikely to be related to a $\mathrm{GABA}_{\mathrm{A}}$-receptor modulation, because pregnenolone and pregnenolone sulfate were inactive in our model (Fig. 5), whereas these two neuroactive steroids are among the most active in paradigms involving the $\mathrm{GABA}_{\mathrm{A}}$ receptors (for review, see Baulieu, 1991). Other mechanisms also have been suggested, such as the existence of steroid recognition sites on the NMDA-receptor complex itself (Irwin et al., 1992). However, such a mechanism could not account for the effect of progesterone in our paradigm, because it did not modify the NMDA response. Nonetheless, the possibility of a downstream action of progesterone at the level of effector mechanisms triggered by $\sigma$-receptor activation cannot be ruled out at present.

Several observations suggest that the selective modulation of the NMDA response by the neuroactive steroids reported here is mediated via $\sigma$ receptors. First, the potentiation induced by DIIEA is suppressed by haloperidol, but not by spiperone (Fig. $1 C$ ). Indeed, spiperone binds with high affinity to dopaminergic, $\alpha_{\mathrm{i}}$-adrenergic, and serotonergic receptors, as does haloperidol (Burt et al., 1977; Clark et al., 1985), but it has a low affinity for $\sigma$-binding sites (Su, 1982; Tam and Cook, 1984; Weber et al., 1986; Steinfels et al., 1989). Second, a low dose $(25 \mu \mathrm{g} / \mathrm{kg}$, i.v. $)$ of the selective $\sigma$ antagonist NE-100 also suppresses the potentiation
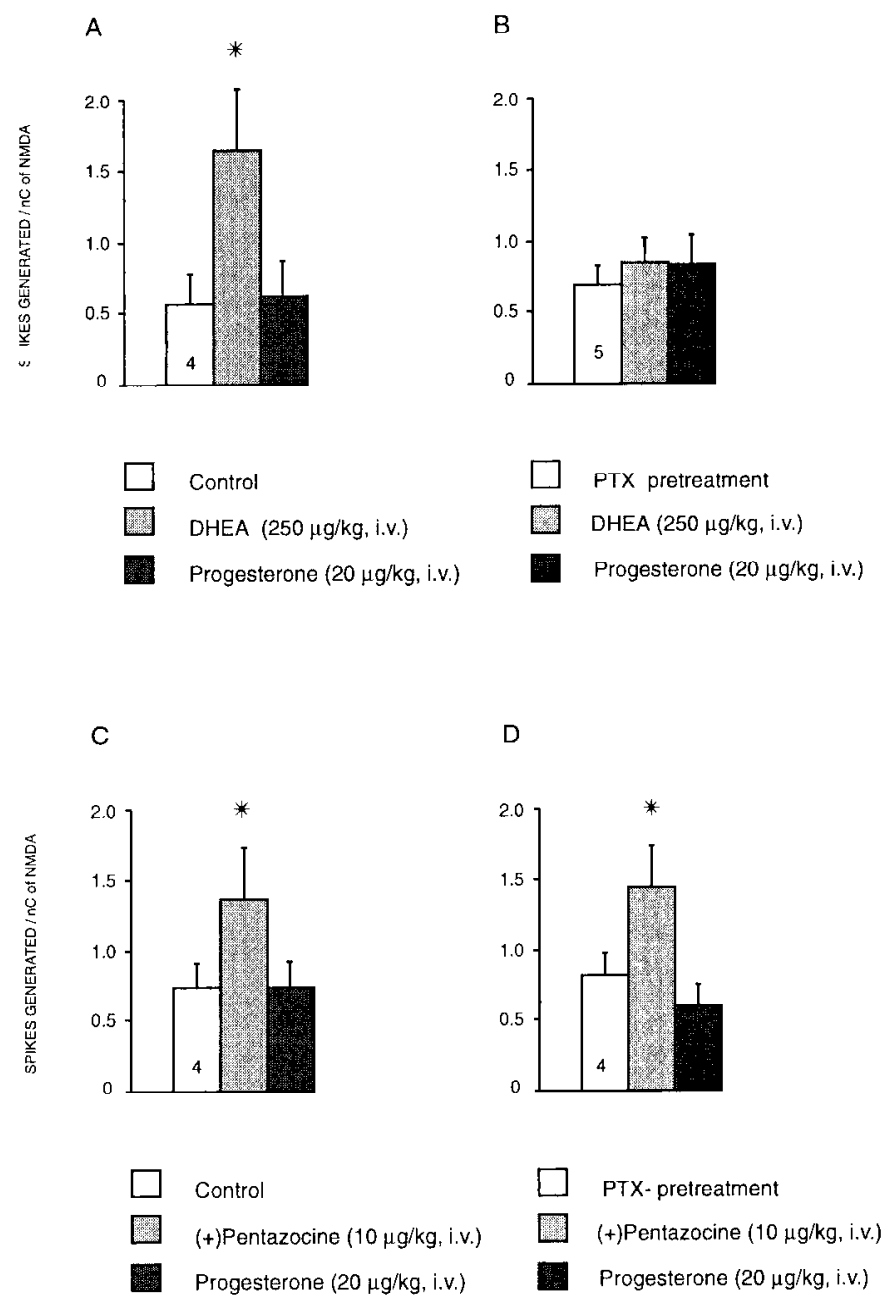

Figure 7. Responsiveness, expressed as the number of spikes generated per $\mathrm{nC}$ (mean $\pm \mathrm{SEM}$ ), of $\mathrm{CA}_{3}$ dorsal hippocampus pyramidal neurons to microiontophoretic applications of NMDA in control rats $(A, C)$ and in PTX-trcatcd rats $(B, D)$ beforc (open columns) and after (gray columns) the administration of DHEA $(A, B)$ or $(+)$ pentazocine $(C, D)$, and after the subsequent administration of progesterone (dark columns). Asterisks indicate $p<0.05$ using paired Student's $t$ test.

of the NMDA response induced by DHEA (Fig. $1 F$ ), as well as the potentiation induced by nonsteroidal $\sigma$ ligands (Debonnel et al., 1995a,b). Third, low doses of progesterone prevent and suppress not only the potentiating effect of DHEA, but also those induced by the selective nonsteroidal $\sigma$ ligands DTG, JO-1784, L-687384, and $(+$ )pentazocine (Figs. 2-4). Fourth, pregnenolone and pregnenolone sulfate, which have low affinity for $\sigma$ receptors (Su et al., 1988), neither prevent nor suppress the potentiation of the NMDA response by DHEA and by the nonsteroidal $\sigma$ agonists even when administered at doses up to $2 \mathrm{mg} / \mathrm{kg}$, i.v. Moreover, our hypothesis is supported by a recent report showing that neuroactive steroids modulate, via $\sigma$ receptors, the $\left[{ }^{3} \mathrm{H}\right]$ norepinephrine release evoked by NMDA in the rat hippocampus (Monnet et al., 1995).

After the intravenous administration of DHEA $(200 \mu \mathrm{g} / \mathrm{kg})$, microiontophoretic application of DTG $(20 \mathrm{nA})$ was ineffective in enhancing the NMDA response further (Fig. 6). Moreover, when DTG was applied microiontophoretically $(20 \mathrm{nA})$, the intravenous injection of DHEA was ineffective in enhancing the NMDA response further (Fig. 6). The occurrence of these bilateral occlu- 

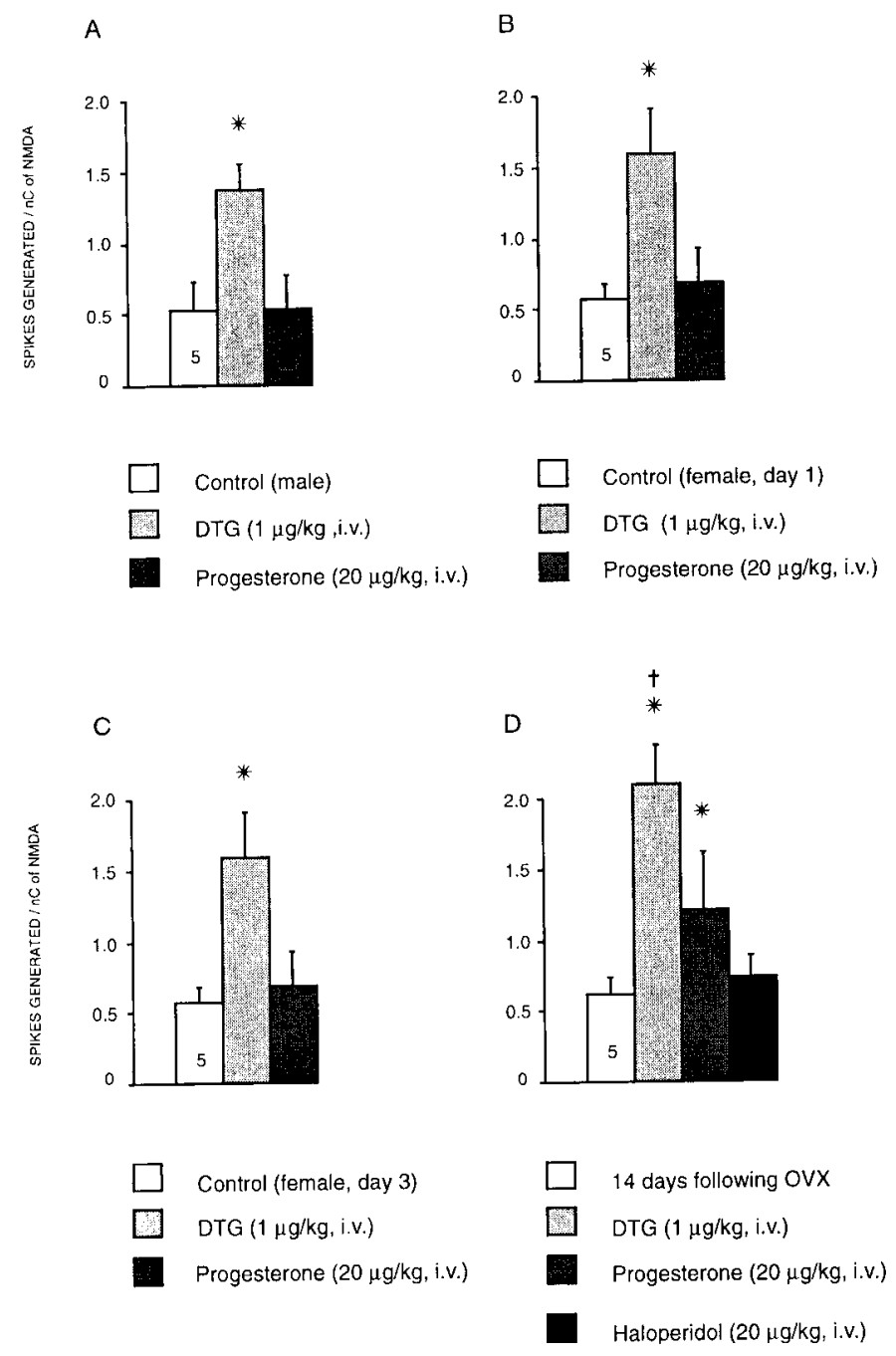

Figure 8. Responsiveness, expressed as the number of spikes generated per $\mathrm{nC}$ (mean $\pm \mathrm{SEM}$ ), of $\mathrm{CA}_{3}$ dorsal hippocampus pyramidal neurons to microiontophoretic applications of NMDA before (open columns) and after (gray coltumns) the administration of DTG and after the subsequent administration of progesterone (dark gray columns) and haloperidol (black column). Asterisks indicate $p<0.05$ using paired Student's $t$ test. $\dagger$ indicates $p<0.0001$ comparing the effect of DTG with that in male and non-OVX female rats using covariance analysis.

sion phenomena provides additional evidence that the potentiation of the NMDA response by DHEA is mediated by $\sigma$ receptors.

We have reported previously that several nonsteroidal $\sigma$ ligands exhibit a bell-shaped dose-response curve (Bergeron et al., 1993, 1995a). This cffect docs not appear to be attributable to a rapid desensitization of $\sigma$ receptors but, rather, to the sequential activation of distinct subtypes of $\sigma$ receptors (Bergeron et al., 1995a). DHEA does not present such a bell-shaped dose-response curve, but plateaus at doses higher than $500 \mu \mathrm{g} / \mathrm{kg}$, i.v. (Fig. $1 B$ ). This suggests that DHEA acts on only one subtype of $\sigma$ receptor. The facts that the potentiating effect of DHEA was suppressed by PTX pretreatment and by the selective $\sigma_{1}$ antagonist NE-100 suggest that the effect of DHEA is mediated via $\sigma_{1}$ receptors. Moreover, after the inactivation of $G_{i / o}$-proteins by a PTX pretreatment, the intravenous administration of DHEA fails to modify the neuronal response to NMDA (Fig. 6), suggesting that the potentiating effect of DHEA on the NMDA response results from the activation of $\sigma_{1}$ receptors coupled to $G_{i / o}$-proteins. We have reported previously that PTX pretreatment does not affect the potentiation of the NMDA response induced by $(+)$ pentazocine, but suppresses those induced by DTG and JO-1784 (Monnet et al., 1994). Thus, it appears that DHEA activates a different $\sigma_{1}$ receptor from that activated by $(+)$ pentazocine. Interestingly, progesterone reverses the persistent potentiating effect of $(+)$ pentazocine in PTX-rats (Fig. 6D), as is the case for haloperidol (Monnet et al., 1994), which suggests that, in contrast to DHEA, progesterone acts on more than one subtype of $\sigma$ receptor. The fact that the potentiation of NMDA-induced neuronal response observed in vitro by Bowlby (1993) with pregnenolone sulfate was not suppressed after a PTX pretreatment constitutes another argument suggesting that pregnenolone sulfate (in his paradigm) and DHEA (in our model) modulate the NMDA response via distinct mechanisms.

No significant difference was found in the degrees of potentiation of the NMD $\Lambda$ response induced by DTG in male and nonOVX female rats. However, a significant increase in the magnitude of this potentiation was observed in OVX rats (Fig. 7). This may be attributable, at least in part, to the fact that OVX decreases the levels of progesterone. Indeed, because this steroid appears to be a potent antagonist of $\sigma$ receptors, the low levels of progesterone in the OVX rats may account for the greater potentiation of the NMDA response by DTG. This would imply that the NMDA response is dampened tonically by progesterone. In keeping with this interpretation, there is a marked reduction in the effectiveness of DTG in potentiating the NMDA response during late pregnancy (Bergeron et al., 1995b), a period during which progesterone levels are very high (Schwarz et al., 1989). Given the very low doses of progesterone administered in the present study, one can assume that its effect is of physiological relcvance.

In conclusion, DHEA and progesterone appear to act as potent modulators at $\sigma$ receptors. Because the prototypical $\sigma$ ligand SKF-10047 produces marked neuropsychological perturbations in humans, the well known neuropsychological effects of neuroactive steroids in the course of the menstrual cycle or pregnancy might be related, at least in part, to alterations of neuronal responsiveness to NMDA via a modulation of $\sigma$-receptor function.

\section{REFERENCES}

Barnes JM, Barnes MN, Barber PC, Champaneria S, Costall B, Hornsby CD, Ironside JW, Naylor RJ (1992) Pharmacological comparison of the sigma recognition site labelled by $\left[{ }^{3} \mathrm{H}\right]$ haloperidol in human and rat cerebellum. Naunyn Schmiedebergs Arch Pharmacol 345:197-202.

Baulieu EE (1991) Neurosteroids: a new function in the brain. Biol Cell $71: 3-10$.

Bergeron R, Debonnel G, De Montigny C (1993) Modification of the $\mathrm{N}$-methyl-D-aspartate response by antidepressant sigma receptor ligands. Eur J Pharmacol 240:319-323.

Bergeron R, De Montigny C, Debonnel G (1995a) Biphasic effects of sigma ligands on the neuronal response to $N$-methyl-D-aspartate. Naunyn Schmiedebergs Arch Pharmacol 351:252-260.

Bergeron R, De Montigny C, Debonncl G (1995b) The potentiation of the NMDA response induced by $\sigma$ ligands is markedly reduced during pregnancy. Soc Neurosci Abstr 21:631.

Bowlby MR (1993) Pregnenolone sulfate potentiation of $N$-methyl-Daspartate receptor channels in hippocampal neurons. Mol Pharmacol 43:813-819.

Burt DR, Creese I, Snyder SH (1977) Antischizophrenic drugs: chronic treatment elevates dopamine receptor binding in brain. Science 196:326-328

Chaki S, Tanaka M, Muramatsu M, Otomo S (1994) NE-100, a novel potent $\sigma$ ligand, preferentially binds to $\sigma_{1}$ binding sites guinea pig brain. Eur J Pharmacol 251:R1-R2.

Clark D, Engberg G, Pileblad E, Svensson TH, Carlsson A, Freeman AS, Bunney BS (1985) An electrophysiological analysis of the action of the 
3PPP enantiomers on the nigrostriatal dopamine system. Naunyn Schmiedebergs Arch Pharmacol 329:344-354.

Debonnel G (1993) Current hypotheses on sigma receptors and their physiological role: possible implications in psychiatry. $\mathbf{J}$ Psychiatry Neurosci $18: 157-172$.

Debonnel G, Bergeron R, Gronier B, Lavoie N, Rettori MC, Guardiola B (1995a) Modulation of NMDA ncuronal response by sigma, and sig$\mathrm{ma}_{2}$ ligands. Soc Neurosei Abstr 21:631.

Debonnel G, Bergeron R, Monnet F, De Montigny C (1995b) Differential effects of sigma ligands on the NMDA response in the CAl and CA3 regions of dorsal hippocampus: effects of mossy fiber lesioning. Neuroscience, in press.

Ferris CD, Hirsch DJ, Brooks BP, Snowman AM, Snyder SH (1991) $\left[{ }^{3} \mathrm{H}\right]$ Opipramol labels a novel binding site and sigma receptors in rat brain membranes. Mol Pharmacol 39:199-204.

Haigler HJ, Aghajanian GK (1974) Lysergic acid diethylamide and serotonin: a comparison of effects on serotonergic neurons receiving a serotonergic input. J Pharmacol Exp Ther 168:688-699.

Irwin RP, Maragakis NJ, Rogawski MA, Purdy RH, Farb DH, Paul SM (1992) Pregnenolone sulfate augments NMDA receptor mediated increases in intracellular $\mathrm{Ca}^{2+}$ in cultured rat hippocampal ncurons. Neurosci Lett 141:30-34.

Itzhak Y, Kassim CO (1990) Clorgyline displays high affinity for sigmabinding sites in C57BL/6 mouse brain. Eur J Pharmacol 176:107-108.

Kandel ER, Spencer WA (1961) Electrophysiology of hippocampal neurons. II. After potentials and repetitive firing. J Neurophysiol 24:243-259.

Lambert JJ, Peters JA, Cottrell GA (1987) Actions of synthetic and endogenous steroids on the GABAa receptor. Trends Pharmacol Sci $8: 224-227$.

Largent BL, Gundlach AL, Snyder SH (1984) Psychotomimetic opiate receptors labelled and visualized with $(+)\left[{ }^{3} \mathrm{H}\right] 3-3$ (3-hydroxyphenyl)N-(1-propyl)piperidine. Proc Natl Acad Sci USA 81:4983-4987.

Maione S, Berrino L, Vitagliano S, Leyva J, Rossi F (1992) Pregnenolone sulfate increases the convulsant potency of $N$-methyl-D-aspartatc in mice. Eur J Pharmacol 219:477-479.

Majewska MD, Schwartz RD (1987) Pregnenolone sulfate: an endogenous antagonist of the $\gamma$-aminobutyric acid receptor complex in brain. Brain Res 404:355-360.

Majewska MD, Demirgoren S, Spivak CE, London ED (1990) The neurosteroid dehydroepiandrosterone sulfate is an allosteric antagonist of the GABAa receptor. Brain Res 526:143-146.

Majewska MD, Harrison NL, Schwartz RD, Barker JL, Paul SM (1986) Steroid hormone metabolites are barbiturate-like modulators of the GABA receptor. Science 232:1004-1007.

Martin WJ, Roth JS, Walker JM (1992) The effects of sigma compounds on both NMDA- and non NMDA-mediated neuronal activity in rat hippocampus. Soc Neurosci Abstr 18:16.

McCanm DJ, Weissman AD, Su T-P (1994) Sigma-1 and sigma-2 sites in rat brain: comparison of regional, ontogenetic, and subcellular patterns. Synapse 17:182-189.

Middlemiss DN, Billington D, Chambers M, Hutson PH, Knight A, Russell M, Thorn L, Tricklebank MD, Wong EHF (1991) L-687,384 is a potent, selective ligand at the central sigma recognition site. $\mathrm{Br} \mathrm{J}$ Pharmacol 102-153.

Mienville JM, Vicini S (1989) Pregnenolone sulfate antagonizes GABAa receptor-mediated currents via a reduction of channel opening frequency. Brain Res 489:190-194.

Monnet FP, Debonnel G, Bergeron R, Gronier B, De Montigny C (1994) The effects of sigma ligands and of neuropeptide $\mathrm{Y}$ on $N$-methyl-Daspartate-induced neuronal activation of $\mathrm{CA}_{3}$ dorsal hippocampus neurones are differentially affected by pertussin toxin. $\mathrm{Br} \mathrm{J}$ Pharmacol 112:709-715.

Monnet FP, Debonnel G, De Montigny C (1992) In vivo electrophysiological evidence for a selective modulation of $N$-methyl-D-aspartateinduced neuronal activation in rat CA3 dorsal hippocampus by sigma ligands. J Pharmacol Exp Ther 261:123-130.

Monnet FP, Debonnel G, Junien JL, De Montigny C (1990) N-methylD-aspartate-induced neuronal activation is selectively modulated by sigma receptors. Eur J Pharmacol 179:441-445.

Monnet FP, Mahé V, Robel P, Baulieu E-E (1995) Neurosteroids, via $\sigma$ receptors, modulate the $\left[{ }^{3} \mathrm{H}\right]$ norepinephrine release evoked by
$N$-methyl-D-aspartate in the rat hippocampus. Proc Natl Acad Sci USA 92:3774-3778.

Morrow AL, Pace RH, Purdy RH, Paul SM (1990) Characterization of steroid interactions with $\gamma$-aminohntyric acid receptor-gated chloride ion channels: evidence for multiple steroid recognition sites. Mol Pharmacol 37:263-270.

Okuyama S, Imagawa $\mathrm{Y}$, Ogawa S, Araki $\mathrm{H}$, $\Lambda$ jima $\Lambda$, Tanaka $\mathrm{M}$, Muramatsu M, Nakazato A, Yamaguchi K, Yoshida M, Otomo $S$ (1993) NE-100, a novel sigma receptor ligand: in vivo tests. Life Sci 53:PL285-PL290.

Paul MS, Purdy RH (1992) Neuroactive steroids. FASEB J 6:2311-2322.

Paxinos G, Watson C (1986) The rat brain in stereotaxic coordinates, 2nd Ed. Orlando: Academic.

Purdy RH, Morrow AL, Moore PH, Paul SM (1991) Stress-induced elevations of $\gamma$-aminobutyric acid type A receptor-active steroids in the rat brain. Proc Natl Acad Sci USA 88:4553-4557.

Quirion R, Bowen WD, Itzhak Y, Junien JL, Musacchio JM, Rothman RB, Su T-P, Tam SW, Taylor DP (1992) A proposal for the classification of sigma binding sites. Trends Pharmacol Sci 13:85-86.

Ramamoorthy JD, Ramamoorthy S, Mahesh VB, Leibach FH, Ganapathy $V$ (1995) Cocaine-sensitive sigma-receptor and its interaction with steroid hormones in the human placental syncytio trophoblast and in choriocarcinoma cells. Endocrinology 136:924-932.

Roman FJ, Pascaud X, Martin B, Vauche D, Junien JL (1990) JO-1784, a potent and selective ligand for rat and mouse brain sigma sites. $J$ Pharm Pharmacol 42:439-440.

Schmidt A, Lebel L, Koe BK, Seeger T, Heym J (1989) Scrtralinc potently displaces $(+)-\left[{ }^{3} \mathrm{H}\right] 3$-PPP binding to sigma-sites in rat brain. Eur J Pharmacol 165:335-336.

Schwarz S, Pohl P, Zhou GZ (1989) Steroid binding at sigma-"opioid" receptors [letter]. Science 246:1635-1638.

Snyder SH, Largent BL (1989) Receptor mechanisms in antipsychotic drug action: focus on sigma receptors. J Neuropsychiatry Clin Neurosci $1: 7-15$.

Stcinfels GF, Alberici GP, Tam SW, Cook L (1988) Biochemical, behavioral, and electrophysiologic actions of the selective sigma receptor ligand (+)-pentazocine. Neuropsychopharmacology 1:321-327.

Steinfels GF, Tam SW, Cook L (1989) Electrophysiological effects of selective sigma-receptor agonists, antagonists, and the selective phencyclidine receptor agonist MK-801 on midbrain dopamine neurons. Neuropsychopharmacology 2:201-208.

Su T-P (1982) Evidence for sigma opioid receptor: binding of $\left.\left.\right|^{3} H\right]$ SKF10047 to etorphine-inaccessible sites in guinea-pig brain. J Pharmacol Exp Ther 223:284-290.

Su T-P, London ED, Jaffe JH (1988) Steroid binding at sigma receptors suggests a link between endocrine, nervous, and immune systems. Science 240:219-221.

Tam SW, Cook L (1984) Sigma opiates and certain antipsychotic drugs mutually inhibit ( 1 ) $-\left[{ }^{3} \mathrm{H}\right]$ SKF 10,047 and $\left[{ }^{3} \mathrm{H}\right]$ haloperidol binding in guinea pig brain membranes. Proc Natl Acad Sci USA 81:5618-5621.

Taylor DP, Dekleva J (1987) Potential antipsychotic BMY $148(12$ selectively binds to sigma sites. Drug Dev Res 11:65-70.

Walker JM, Hunter WS (1994) Role of sigma receptors in motor and limbic system function. Neuropsychopharmacology [Suppl] 10:837s.

Walker JM, Bowen WD, Walker FO, Matsumoto RR, de Costa B, Rice KC (1990) Sigma receptors: biology and function. Pharmacol Rev 42:355-402.

Weber E, Sonders M, Quarum M, McLean S, Pou S, Keana JF (1986) $1,3-\mathrm{Di}\left(2-\left[5-{ }^{-3} \mathrm{H}\right]\right.$ tolyl)guanidine: a selective ligand that labels sigma-type receptors for psychotomimetic opiates and antipsychotic drugs. Proc Natl Acad Sci USA 83:8784-8788.

Wolfe Jr SA, Culp SG, De Souza EB (1989) Sigma-receptors in endocrine organs: identification, characterization, and autoradiographic localization in rat pituitary, adrenal, testis, and ovary. Endocrinology $124: 1160-1172$.

Wu FS, Gibbs TT, Farb DH (1990) Inversc modulation of $\gamma$-aminobutyric acidand glycine-induced currents by progesterone. Mol Pharmacol 37:597-602.

Wu FS, Gibbs TT, Farb DH (1991) Pregnenolone sulfate: a positive allosteric modulator at the $N$-methyl-D-aspartate receptor. Mol Pharmacol 40:333-336.

Yamada M, Nishigami T, Nakasho K, Nishimoto Y, Miyaji H (1994) Relationship between sigma-like site and progesterone-binding site of adult male rat liver microsomes. Hepatology 20:1271-1280. 